\title{
THE EFFECTS OF CAR WASH OPERATION ON THE BRAZILIAN CAPITAL MARKET: THE PETROBRAS CASE
}

\author{
ELIANA M. M. F. TORGA ${ }^{1}$ \\ (D) https://orcid.org/0000-0003-4175-9390 \\ CAROLINA M. S. ROMA² \\ (iD) https://orcid.org/0000-0003-1156-7558 \\ MIRIAN A. PIRES 3 \\ (iD) https://orcid.org/0000-0001-8975-9280 \\ PAULA M. S. ROMA 4 \\ (D) https://orcid.org/0000-0002-3625-9837 \\ BRUNO P. FERREIRA 5 \\ (D) https://orcid.org/0000-0002-1011-5253
}

To cite this paper: Torga, E. M. M. F., Roma, C. M. S., Pires, M. A., Roma, P. M. S., \& Ferreira, B. P. (2021). The effects of Car Wash Operation on the Brazilian capital market: The Petrobras case. Revista de Administração Mackenzie, 22 (2), 1-26. doi:10.1590/1678-6971/eRAMF210018

Submission: Feb. 19, 2020. Acceptance: May 28, 2020.

1 UNA University Center, Belo Horizonte, MG, Brazil.

2 Federal University of Rio Grande (Furg), Rio Grande, RS, Brazil.

3 Federal University of Espírito Santo (Ufes), Vitória, ES, Brazil.

4 Federal Institute of Education, Science and Technology of South of Minas Gerais (IFSULDEMINAS), Três Corações, MG, Brazil.

5 Federal University of Minas Gerais (UFMG), Belo Horizonte, MG, Brazil.

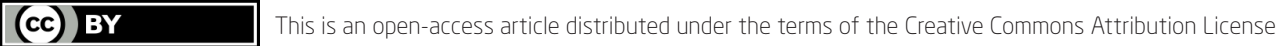

\footnotetext{
This paper may be copied, distributed, displayed, transmitted or adapted for any purpose, even commercially, if provided, in a clear and explicit way, the name of the journal, the edition, the year and the pages on which the paper was originally published, but not suggesting that RAM endorses paper reuse. This licensing term should be made explicit in cases of reuse or distribution to third parties.

Este artigo pode ser copiado, distribuído, exibido, transmitido ou adaptado para qualquer fim, mesmo que comercial, desde que citados, de forma clara e explícita, o nome da revista, a edição, o ano e as páginas nas quais o artigo foi publicado originalmente, mas sem sugerir que a RAM endosse a reutilização do artigo. Esse termo de licenciamento deve ser explicitado para os casos de reutilização ou distribuição para terceiros.
} 


\section{ABSTRACT}

Purpose: The study aimed to identify the effects of the Car Wash Operation on the Brazilian capital market, focusing on the state-owned company Petróleo Brasileiro S.A. (Petrobras), including in the analysis other publicly traded companies that belong to the oil and gas sector.

Originality/value: This research is relevant because it advances in discussing the influence of the Car Wash Operation on the stock price in the Brazilian context. This study contributes to revealing the use of the Google Trends tool to measure market attention and its effects.

Design/methodology/approach: This is a quantitative research based on evidence of the volume of research in relation to the movement of the stock prices. The sample consisted of data from Petrobras and other companies belonging to the oil and gas sector in the period from January 2, 2013, to December 28, 2018. The most relevant dates were defined through the search volume index for the terms "Car Wash" and "corruption", obtained from the Google Trends tool. The GARCH model $(1,1)$ was adopted in the estimates.

Findings: The results obtained from the dummies inserted to capture the abnormal returns showed a significant reaction in the behaviors of the assets. The flow of capital seems to have opted for assets of greater confidence than PETR3 and PETR4 in a few weeks of the Operation. This work showed that, in general, the outbreak of the Car Wash Operation influenced and brought some instability to other companies in the sector.

\section{KEYWORDS}

Car Wash Operation. Corruption. Petrobras. Investor sentiment. Google Trends. 


\section{INTRODUCTION}

Starting in 2014, the Brazilian economy entered into a recession, according to the Economic Cycle Dating Committee (Codace) of the Getulio Vargas Foundation (FGV, 2017). According to Barbosa Filho (2017), the depth of this recession was the result of a series of supply and demand shocks that hit the Brazilian economy and were caused by economic policy errors, particularly during the period when the policies that formed the "New Economic Matrix" were adopted. This corresponded to the monetary policy of Brazil between 2011 and 2012, with strong government intervention (Pessôa, 2017). For this author, the economic crisis had exogenous factors, such as the international increase in the oil price, besides recognizing that the fight against corruption had an important influence.

The fall of $3.05 \%$ in the gross domestic product (GDP) in the crisis context (Central Bank of Brazil, 2015), the uncertainty and distrust generated by high government spending, and the increase in interest rates, resulted in a crisis that affected Brazilian companies, with a potential decrease of the value of the assets in the market (Padula \& Albuquerque, 2018). In this context, on March 17, 2014, the Brazilian Federal Police (PF) launched the operation known as Car Wash (CW) (Federal Police, 2019), conducted by the Federal Prosecutor's Office (MPF) and by the Federal Police, which is still active in 2020.

The CW Operation investigates corrupt practices uncovered by testimonies of executives and politicians involved in money laundering (Connors \& Magalhaes, 2015). Studies have analyzed the factors that caused the economic downturn from 2011 onwards, worsening in 2014. Borges (2017) pointed out that 40 to $60 \%$ of the deceleration in the GDP growth in 20122016 was the result of international factors whereas the domestic ones were related to the impact of this operation. It is difficult to isolate the factors and their influence, but CW is regarded as an important anti-corruption project in the medium and long terms, although resulting in short term economic instability (Borges, 2017).

Petróleo Brasileiro S.A. (Petrobras), the largest Brazilian company in the oil and gas sector, accounting for a significant share of national investments (OECD, 2015), was one of the major companies involved, contributing to producing an atmosphere of national instability, with international consequences. A cutback of $\mathrm{R} \$ 21.6$ billion was identified in 2014 due to an impairment loss of $\mathrm{R} \$ 44.6$ billion; and a $\mathrm{R} \$ 6.2$ billion loss due to undue 
payments identified by the CW Operation (Petrobras, 2014). Thus, in this operation, this company was the target of an investigation that affected not only the company itself but also the whole country, in addition to scandals that caused the discrediting of public institutions and the decline of confidence by investors (Ebeling, 2016).

In an environment of uncertainty and low confidence among individuals, decisions are influenced by emotion rather than reason. Trust is a cognitiverelational concept defined as a firm belief in the reliability of a particular issue that arises under conditions of unknown results (Corgnet, Espín, Hernán-González, Kujal, \& Rassenti, 2016). Thus, investors tend to act motivated by "market sentiment", which sometimes tends to pessimism and sometimes to optimism, resulting in biases responsible for volatility and speculative bubbles (Fenton-O'Creevy, Soane, Nicholson, \& Willman, 2011; Prosad, Kapoor, \& Sengupta, 2015).

In view of this, this study aimed to identify the effects of $\mathrm{CW}$ on the Brazilian capital market, opting for analyzing Petrobras and including in the analysis other publicly traded companies that belong to the oil and gas sector for comparison purposes. The inspiration for this research is based on the work of Sabet, Cam, and Heaney (2012), who investigated the reaction in BP plc prices following the explosion of its Deepwater Horizon oil rig in the Gulf of Mexico and subsequent events, including in the analysis the subcontractors of BP and other companies in the oil and gas sector.

The results reported indicate that the $\mathrm{CW}$ brought abnormal negative returns for Petrobras assets and that the dummies representing the weeks of greatest search on the internet for the term "Car Wash" captured a significant movement of abnormal negative and positive returns, not only for Petrobras but also for other companies in the sector. For the expression "corruption", which was searched due to the context of the operation, there were indications that the dates related to this increased search volume and its effects do not seem to be linked to the negative aspects of the CW, although they played a significant role on the stock returns of the companies of this sector.

This research contributes to broadening the discussions about investor attention and sentiment towards $\mathrm{CW}$ and its influence on stock prices in the Brazilian context, offering new evidence about the use of the Google Trends tool. This study is justified since there are few studies in the national literature about this topic. Therefore, it aimed to bring new evidence not only about Petrobras but also about other companies. 


\section{LITERATURE REVIEW}

The following literature review is divided into three topics: "Corruption cases worldwide", "Investments and corruption", and "Investor sentiment".

\subsection{Corruption cases worldwide}

When we look at the global context, other countries have been involved in corruption cases (Warf, 2019). By making an association with countries that adopt Civil Law (Falcão \& Bonato, 2017), it is possible to identify several cases of corruption in Latin America, including Argentina, Bolivia, Peru, Mexico, Honduras, and Guatemala. In these countries, there are cases of corruption involving politicians and their families, as well as fraud in elections, links with drug trafficking and criminal organizations, and implications in the diversion of public money (Rotberg, 2019; Warf, 2019).

On the other hand, when we analyze Europe, where there are countries that adopt both Common Law and Civil Law (Bulnes, 2013; Falcão \& Bonato, 2017), we realize that there are fewer cases of corruption. This might be explained by the fact that these countries have strict policies, besides being rich countries and presenting relatively free media (Brunetti \& Weder, 2003; Jain, 2001).

Regarding Oceania, a region characterized by the adoption of Common Law (Falcão \& Bonato, 2017), countries such as Australia and New Zealand have the lowest corruption rates on the continent. However, it should be made clear that corruption generally presents a correlation with local development, given that the most corrupt countries are classified as developing markets, whose population behaves in a tolerant manner (Barkemeyer, Preuss, \& Ohana, 2018).

\subsection{Investment and corruption}

Corruption is one of the greatest opponents of trade, as fair investors have difficulty accessing the market due to the adoption of bribery practices. There is evidence that corruption increases the total cost of business in up to $10 \%$ and the cost of acquisition contracts in developing countries in up to $25 \%$ (Bonell \& Meyer, 2015), acting as a disease that affects society. Corruption is believed to affect the economy by distorting decision-making and rewarding corrupt people at the expense of the efficient and productive ones (Voyer \& Beamish, 2004). 
It is worth noting that corruption decreases investment and employment growth, reducing the competitiveness of companies (Campos, Lien, \& Pradhan, 2008). There are also works based on the real incidence of corruption cases, making it evident that corruption is a decisive factor affecting capital inflows (Vuuren, 2002), investment, and local growth (Mauro, 1995).

Thus, corruption is considered to have a direct effect on investor sentiment, perception, and behavior, affecting the decision to invest in a certain place (Vuuren, 2002), mainly in Latin American and sub-Saharan African countries (Asiedu \& Freeman, 2009). In addition, evidence was found that American investors are more likely not to invest in corrupt countries (Hines, 1995).

However, countries such as China, Brazil, or Argentina receive foreign investment inflows despite the existing corruption (Habib \& Zurawicki, 2002). This reality is due to the fact that the impact of corruption is weakened by positive factors, such as the openness of the economy and political stability, influencing the behavior of investors.

\subsection{Investor sentiment}

Taffler and Tucket (2010) point out that financial markets are essentially social environments in which individuals engage with each other to set asset prices that reflect opinions about the future in these markets. Investment activity depends on judgments about the information available to resolve two orders of uncertainty: that caused by information asymmetries at the time of decision-making; and that determined by the fact that the future is unknown.

According to these authors, this variety of constraints that affect the investor behavior may be used by speculators trading on the stock exchange, with the predominance of reason. In itself, this rational action about the non-rationality of the investor, predominantly emotional, may configure and result in biases (Taffler \& Tuckett, 2010).

Some studies published internationally and nationally have demonstrated the influence of investor sentiment on financial decisions (Baker \& Wurgler, 2007; Yoshinaga, 2009) in the formation of overly optimistic or pessimistic accounting profit expectations by analysts and investors and how these profit forecasts affect the relation between investor sentiment and stock returns (Santana, Santos, Carvalho Júnior, \& Martinez, 2020). 


\section{METHODOLOGICAL PROCEDURES}

This section presents the data used in the research and details the procedures employed to obtain the final sample, the selection criteria for the relevant dates linked to the $\mathrm{CW}$, and the estimation of abnormal returns.

\subsection{Data and sample}

In order to identify the possible effects of the CW Operation, Petrobras and other publicly traded companies belonging to the oil and gas sector that have available data were included in this study, inspired by the Sabet et al. (2012) research. By including other companies from the same sector, it is possible to identify whether the studied effects are homogeneous or not, since they do not affect only the company targeted by the investigations (Petrobras), allowing a comparative analysis. The CW Operation, which was launched on March 17, 2014, started a long period of corruption news involving Petrobras. Thus, the observation period runs from January 2, 2013, to December 28, 2018, covering 290 days prior to the media exposure, considering a pre-scandal period in order to assess the influence of the CW on the returns of the analyzed companies. This period prior to the event is believed to be compatible with the literature (Sabet et al., 2012).

For model assessment, the adjusted daily closing prices of the shares, the Bovespa index (Ibovespa), representing the Brazilian market portfolio, and the Interbank Deposit Certificate (CDI), a proxy for the risk-free assets, were collected from the Economática ${ }^{\circledR}$ software. The classification of companies by sector refers to that presented in the same database. Future closest-to-maturity prices of the West Texas Intermediate (WTI) crude oil and natural gas traded on the New York Mercantile Exchange (NYMEX) were taken from the website of the US Energy Information Administration (http://www.eia.doe.gov/). The 1 and 3-month DI series used for calculating the slope of the short-term yield curve were obtained from the Investing website (https://www.investing.com/).

The stocks belonging to the oil and gas sector were chosen in order to obtain all the observations that during the investigated period had their price adjusted above $\mathrm{R} \$ 3.00$. After these filters, four companies listed on Brazil, Bolsa, Balcão (B3), representing five assets, were left in the sample, including common and preferred share classes: Petróleo Brasileiro S.A. (Petrobras) - PETR3 and PETR4; Companhia de Gás de São Paulo (Comgás) CGAS5; Cosan S.A. - CSAN3; and Ultrapar Participações S.A. - UGPA3. 
The return of each series was calculated based on the difference between the logarithms of the corresponding prices.

\subsection{Data selection}

The key point in the analysis is to identify the most important dates. The search volume index (SVI) obtained from Google Trends (http://www. google.com/trends) was proposed by Da, Engelberg, and Gao (2011) as a measure of investor attention. The authors showed that, although SVI is correlated with other proxies that attract the investor, it has its own characteristics, distinguishing itself from the others analyzed, being related to the attention of retail investors. Using data from 2004 to 2008, they point out evidence on the Barber and Odean (2008) price pressure hypothesis, in which an increase in the SVI predicts an increase in prices in the short term (two weeks later) and almost total reversal in the price at the end of the year.

Bijl, Kringhaug, Molnár, and Sandvik (2016) studied the period from 2008 to 2013, finding that the SVI obtained from the names of the companies that comprise the S\&P 500 index is able to predict the weekly return on these stocks negatively. However, they have argued that a trading strategy based on this relationship is not feasible when considering transaction costs. Therefore, although in the current period the suggested relationship is reversed, it is possible to detect its influence. Da, Engelberg, and Gao (2015) built the Financial and Economic Attitudes Revealed by Search (Fears) index, a new measure of investor sentiment, based on the search volume terms related to economic conditions such as "crisis", "recession", "bankruptcy", "unemployment", "inflation rate", obtained through Google Trends. They have shown that Fears can (negatively) predict the contemporary return of the S\&P 500 index with an almost complete reversal in the following two days. Thus, the SVI is recognized as a measure of investor attention and sentiment (Da et al., 2011; Kim, Lučivjanská, Molnár, \& Villa, 2019).

Based on the evidence that the search volume is related to the movement of the stock prices, in order to identify the dates that have most attracted the attention of investors, we have chosen to use the SVI of the terms "Car Wash" and "corruption" from Google Trends. Google shows the relative search volume for a given term, being a value between 0 and 100 , in which zero occurs when there are practically no searches on that term, and one hundred is the point in time with the greatest relative access. Since it is only possible to obtain the index in the daily rate for periods of up to 90 days, each series was downloaded on a weekly basis in a week time 
rate, comprising the period from a given Sunday to the following Saturday. Because the operation was started on March 17, 2014, the cut-off was chosen from March 15, 2014, until the end of December 2018, in order to increase the chances of linking the search to what is intended to be measured. In addition, as they refer to stocks of Brazilian companies, searches involving only Brazil were selected. Figure 3.2.1 presents the SVI for the term "Car Wash" and "corruption".

\section{(Figure 3.2.1)}

\section{SVI FOR THE KEYWORDS "CAR WASH" AND "CORRUPTION"}

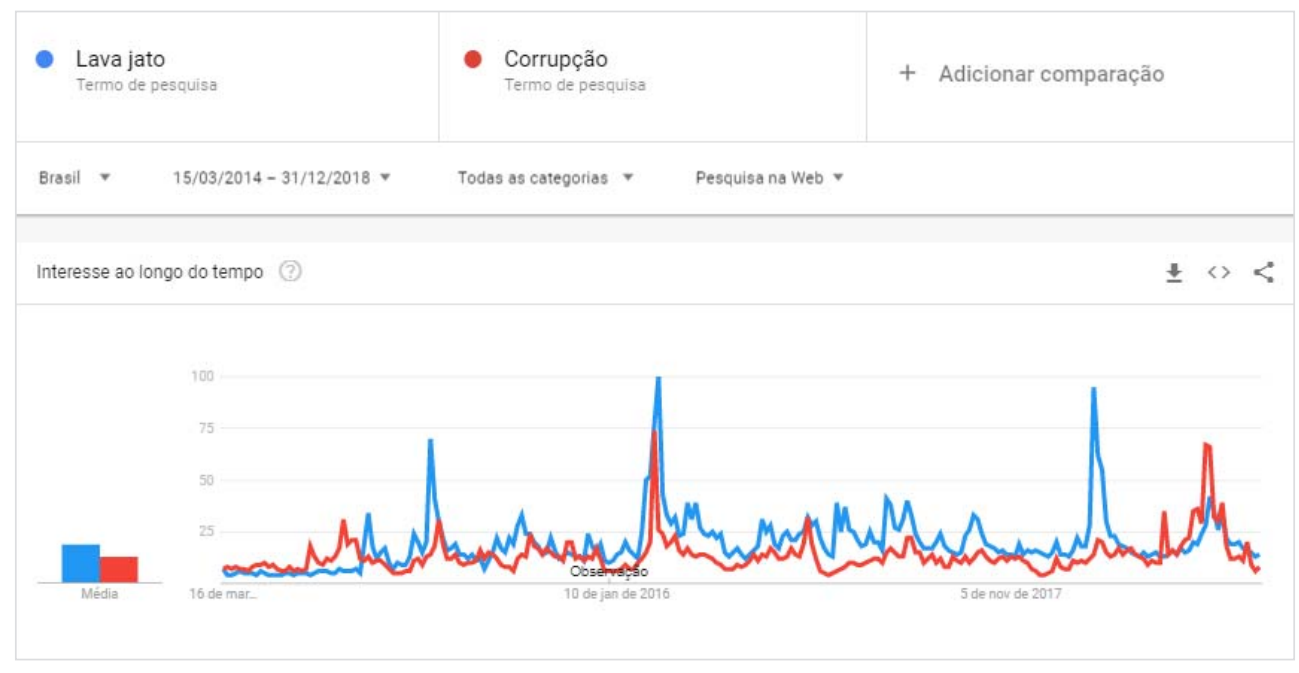

Source: Google Trends (2019).

Figure 3.2.1 shows that the average relative search for the term "Car Wash" exceeded that of the term "corruption" during the analyzed period, as it also shows that there were peaks for the first expression that are not always followed by the second one, making the addition of both relevant. The dates when the SVI was above 50 were selected as those that have received more attention by Google users.

Six weeks were selected for the term "Car Wash": 3/01/2015, 3/13/2016, $3 / 20 / 2016,3 / 25 / 2018,4 / 01 / 2018$, and 4/08/2018. For the term "corruption", three weeks were identified: 03/13/2016, 09/30/2018, and $10 / 07 / 2018$. Note that these dates refer to Sundays, as available on Google Trends, reflecting the search performed in the week immediately before. This pattern of dates is maintained in order to match with the released information, but the time actually spent in the construction of the dummies 
was taken into account when searching for abnormal returns. In addition, the definition of the week for B3 comprises the period from Monday to Friday, differing from the SVI interval. As an adjustment, each week was comprised by the days between two Mondays (included) in order to reflect movements arising from online searches after the closing time of the trading session on Friday.

Two interesting remarks about the dates are: 1 . there was a relative increase of the users' attention for the first term in March 2016, which also covered the dates of the 24th (March 4, 2016), 25th (March 21, 2016), and 26th (March 22, 2016) phases of the CW Operation. This included the investigations related to possible advantages received by the contractors involved, coercive practices, and its first international phase, with the arrest of a Portuguese-Brazilian citizen in Portugal, mentioned in the corruption scheme as being responsible for illicit payments to former directors of Petrobras (Federal Police, 2019); 2. the relative increase of the SVI for the second term coincides with the first round of the electoral period for the presidency of Brazil and other political positions at state and federal levels, and it is also marked by debates about the misuse of public resources.

Thus, dummies were inserted for all days of their respective weeks, according to the mentioned definition, as well as adding a dummy for the days $03 / 17 / 2014$ and $03 / 18 / 2014$ in order to consider the effect of the operation.

\subsection{Abnormal returns}

To investigate the influence of the dates with the highest relative search for the terms "Car Wash" and "corruption", we have analyzed the abnormal returns (Ball \& Brown, 1968; Fama, Fisher, Jensen, \& Roll, 1969; Sabet et al., 2012). We have considered the adjusted market model, including the risk premium, the short-term yield curve slope, and the returns of crude oil and natural gas futures contracts, from the study of Sabet et al. (2012).

For all models under analysis, evidence of autoregressive conditional heteroscedasticity effects was found using the Lagrange Multiplier test proposed by Engle (1982). Thus, the Generalized Autoregressive Conditional Heteroskedasticity (GARCH) model proposed by Bollerslev (1986) was adopted, which is a generalization of the Autoregressive Conditional Heteroskedasticity (ARCH) model of Engle (1982). This author assumes that variance is not homoscedastic over time, being modeled according to its own lagged value, as well as by the past squared residual. The GARCH (1.1), which makes use of only one lag of the conditional variance and squared 
error, was chosen because of its parsimony, having been adopted by Sabet, Cam, and Heaney (2012) in the analysis of companies in the oil and gas sector. Thus, the model is defined in Equation 1:

$$
R_{j, t}=B_{j}+B_{j m} R_{m t}+B_{j b} R_{b t}+B_{j 0} R_{o t}+B_{j g} R_{g t}+\sum_{i=1}^{k} \gamma_{j i} D_{i}+\varepsilon_{j t}
$$

in which: $R_{j, t}$ is the daily return of firm $\mathrm{j}$ in excess of the risk-free asset (CDI) for period $t ; R_{m t}, R_{b t}, R_{o t}$ and $R_{g t}$ represent for each period t, respectively, the excess return of the market portfolio given by the Ibovespa return minus the CDI return, the premium between the three-month DI rate and the onemonth DI rate representing the yield curve slope the return of WTI crude oil from closest-to-maturity futures contract prices and the return of natural gas from closest-to-maturity futures contract prices. $D_{i}$ refers to the dummy variable included in the model to reflect the possible average abnormal return in relation to the event days i. Finally, $\varepsilon_{j t}$ is the error term of the model.

The dates defined in Section 3.2 have been included separately as dummies in order to test the effect of the $\mathrm{CW}$ and corruption in the periods that most attracted the attention of Google users. Since the rate of the SVI is per week and the return data are per day, the value one was used for all days of the week concurrent to the corresponding event, following the already mentioned definition, i.e., from Monday to Monday, and zero, otherwise.

The conditional variance equation is given in Equation 2:

$$
\sigma_{j t}^{2}=\varpi_{j}+\varphi_{j} \varepsilon_{j t-1}^{2}+\eta_{j} \sigma_{j t-1}^{2}
$$

in which: $\sigma_{j t}^{2}$ and $\sigma_{j t-1}^{2}$ represent the conditional variance for day $t$ and the lagged one period, respectively, and $\varepsilon_{j t-1}^{2}$ is the square error in period $t-1$.

The model parameters were estimated using the quasi maximum likelihood estimation (QMLE) method, which is robust for deviations from the normality assumption (White, 1982). The post-estimation tests showed that the model estimated for Comgás (CGAS5) was not able to correct the serial correlation in the standardized residuals at the $5 \%$ significance levels, so, for this case, a lag of the dependent variable was included to filter this effect, although not reported in the tables with the results discussed next. 


\section{RESULTS}

The results are presented in the following subsections. For a better understanding of the analyses, they have been separated into topics: "Descriptive statistics", "Estimation results: Car Wash", and "Estimation results: corruption".

\subsection{Descriptive statistics}

Figure 4.1.1 shows the descriptive statistics for the explanatory variables used in the mean equation. The individual stocks had a positive performance, with the stocks related to Petrobras and Congás showing a similar average return of $10 \%$ per year $(0.0004 \times 250 \times 100)$, while the average performance of CSAN3 was the lowest during the analyzed period with $5 \%$ per year $(0.0002 \times 250 \times 100)$.

(Figure 4.1.1)

DESCRIPTIVE ASSET STATISTICS

\begin{tabular}{lcccc}
\hline & Mean & Standard deviation & Maximum & Minimum \\
\hline PETR3 & 0.0004 & 0.0320 & 0.1497 & -0.1615 \\
\hline PETR4 & 0.0004 & 0.0324 & 0.1509 & -0.1715 \\
\hline CGAS5 & 0.0004 & 0.0172 & 0.0955 & -0.1218 \\
\hline CSAN3 & 0.0002 & 0.0206 & 0.1084 & -0.1048 \\
\hline UGPA3 & 0.0003 & 0.0167 & 0.0832 & -0.1072 \\
\hline Risk premium & -0.0001 & 0.0145 & 0.0633 & -0.0925 \\
\hline Oil futures & -0.0003 & 0.0215 & 0.1162 & -0.1079 \\
\hline Gas futures & 0.0002 & 0.0274 & 0.1651 & -0.1279 \\
\hline DI 3 m- Im & 0.1051 & 0.0296 & 0.2124 & 0.0617 \\
\hline
\end{tabular}

Source: Elaborated by the authors.

The asset with the lowest risk, measured by the standard deviation, was UGPA3, with a value of $26 \%$ per year $(0.0167 \times \sqrt{250} \times 100)$, and that with the highest risk was the preferred share of PetrobrásPetrobras (PETR4), 
with $51 \%$ per year $(0.0324 \times \sqrt{250} \times 100)$. In addition, PETR4 also exhibited the worst drop, reaching a minimum return of $-17 \%$ in the closing interval from one day to the next.

In terms of the market risk factor, the risk premium was negative, on average, signaling the weak performance of the Ibovespa. In addition, the average return on WTI crude oil futures contracts was also negative, although with volatility close to that shown by the daily returns on natural gas futures contracts.

Based on this analysis, we have observed that the asset with the highest volatility was not necessarily the one with the highest return compared to the others. This refers to the traditional financial theory that argues about the existence of a positive relationship between return and risk, as demonstrated in the work of Markowitz (1952). However, studies investigating portfolio formation based on low volatility have empirically pointed out that they have a similar or better performance than those that are more volatile (Blitz, Pang, \& van Vliet, 2013; Clarke, Silva, \& Thorley, 2006). Thus, the findings presented in Figure 4.1.1 suggest evidence in this direction. Moreover, the performance of Petrobras, regarding volatility and the asset with the worst drop, provides initial indications that the $\mathrm{CW}$ did not go unnoticed by investors.

\subsection{Estimates results: Car Wash}

Figure 4.2.1 presents the results of the estimates for the stocks in the sample "Car Wash" search term. Regarding the risk factors in the mean equation, the excess return of the market portfolio is a highly significant variable for all the assets in the sample, providing evidence of the relevance of the market beta to explain the returns of the companies. For the other variables, the negotiation of oil futures contract prices is more relevant, being significant for three of the five assets (PETR3, PETR4, and CSAN3) in the sector, especially for Petrobras. Regarding the adjustment of the variance equation, the ARCH coefficient of the model $\left(\varphi_{j}\right)$ was relevant for four of the five shares, except for UGPA3, while the GARCH coefficient $\left(\eta_{j}\right)$ was significant for each one of the assets in the sample. When added together, they show a persistent behavior, taking time to dissipate, but less than 1 . 


\section{(Figure 4.2.1)}

ABNORMAL RETURN FOR THE DATES FROM THE SEARCH TERM:

"CAR WASH"

\begin{tabular}{|c|c|c|c|c|c|}
\hline Variables & PETR3 & PETR4 & CGAS5 & CSAN3 & UGPA3 \\
\hline \multirow{2}{*}{ Intercept } & -0.0004 & 0.0000 & 0.0004 & -0.0003 & 0.0003 \\
\hline & $(0.0017)$ & $(0.0018)$ & $(0.0017)$ & $(0.0014)$ & $(0.0015)$ \\
\hline \multirow{2}{*}{ Premium risk } & 1.4848 & 1.5659 & 0.2704 & 0.7663 & 0.6213 \\
\hline & $(0.0483)^{\star \star \star}$ & $(0.0502)^{\star \star \star}$ & $(0.0369)^{\star \star \star}$ & $(0.0462)^{\star \star \star}$ & $(0.0366)^{\star \star \star}$ \\
\hline \multirow{2}{*}{ Oil futures } & 0.3509 & 0.3179 & -0.0115 & 0.0513 & -0.0048 \\
\hline & $(0.0282)^{\star \star \star}$ & $(0.0300)^{\star \star \star}$ & $(0.0217)$ & $(0.0231)^{\star \star}$ & $(0.0163)$ \\
\hline \multirow{2}{*}{ Gas futures } & 0.0077 & 0.0038 & 0.0109 & 0.0124 & -0.0073 \\
\hline & (0.0139) & $(0.0141)$ & $(0.0151)$ & $(0.0190)$ & $(0.0131)$ \\
\hline \multirow{2}{*}{ Dl 3m-1 m } & 0.0075 & 0.0044 & -0.0040 & 0.0016 & -0.0026 \\
\hline & $(0.0159)$ & $(0.0172)$ & $(0.0168)$ & $(0.0132)$ & $(0.0132)$ \\
\hline \multirow{2}{*}{$\begin{array}{c}\text { 03/17 and } \\
03 / 18 / 2014\end{array}$} & -0.0099 & -0.0147 & 0.0081 & -0.0102 & 0.0101 \\
\hline & $(0.0008)^{\star \star \star}$ & $(0.0012)^{\star \star \star}$ & $(0.0025)^{\star \star \star}$ & $(0.0007)^{\star \star \star}$ & $(0.0007)^{\star \star \star *}$ \\
\hline \multirow{2}{*}{$\begin{array}{c}\text { Week } 1 \text { - } \\
\text { 03/01/2015 }\end{array}$} & -0.0046 & -0.0049 & -0.0123 & 0.0029 & 0.0063 \\
\hline & $(0.0027)^{\star}$ & $(0.0032)$ & $(0.0032)^{\star \star \star}$ & $(0.0026)$ & $(0.0009)^{\star \star \star}$ \\
\hline \multirow{2}{*}{$\begin{array}{c}\text { Week 2 - } \\
\text { 03/13/2016 }\end{array}$} & -0.0073 & 0.0010 & -0.0008 & 0.0008 & -0.0017 \\
\hline & $(0.0027)^{\star \star \star}$ & $(0.0071)$ & $(0.0015)$ & $(0.0017)$ & $(0.0009)^{\star}$ \\
\hline \multirow{2}{*}{$\begin{array}{c}\text { Week } 3 \text { - } \\
\text { 03/20/2016 }\end{array}$} & -0.0047 & -0.0092 & -0.0008 & 0.0066 & 0.0020 \\
\hline & $(0.0025)^{\star}$ & $(0.0055)^{*}$ & $(0.0016)$ & $(0.0018)^{\star \star \star}$ & $(0.0029)$ \\
\hline \multirow{2}{*}{$\begin{array}{c}\text { Week } 4 \text { - } \\
\text { 03/25/2018 }\end{array}$} & 0.0017 & 0.0027 & -0.0031 & -0.0041 & -0.0047 \\
\hline & $(0.0014)$ & $(0.0010)^{\star \star \star}$ & $(0.0015)^{\star \star}$ & $(0.0022)^{\star}$ & $(0.0020)^{\star \star}$ \\
\hline \multirow{2}{*}{$\begin{array}{c}\text { Week } 5 \text { - } \\
\text { 04/01/2018 }\end{array}$} & -0.0077 & -0.0075 & 0.0039 & -0.0042 & 0.0050 \\
\hline & $(0.0012)^{\star \star \star}$ & $(0.0014)^{\star \star \star}$ & $(0.0013)^{\star \star \star}$ & $(0.0014)^{\star \star \star}$ & $(0.0023)^{\star \star}$ \\
\hline \multirow{2}{*}{$\begin{array}{c}\text { Week } 6 \text { - } \\
\text { 04/08/2018 }\end{array}$} & 0.0059 & 0.0019 & -0.0042 & -0.0071 & -0.0071 \\
\hline & $(0.0016)^{\star \star \star}$ & $(0.0016)$ & $(0.0012)^{\star \star \star}$ & $(0.0009)^{\star \star \star}$ & $(0.0067)$ \\
\hline \multirow{2}{*}{ C } & 0.0000 & 0.0000 & 0.0000 & 0.0000 & 0.0000 \\
\hline & $(0.0000)^{\star \star}$ & $(0.0000)^{\star \star \star}$ & $(0.0000)^{\star \star}$ & $(0.0000)^{\star \star}$ & $(0.0000)$ \\
\hline
\end{tabular}




\section{(Figure 4.2.1 (conclusion))}

ABNORMAL RETURN FOR THE DATES FROM THE SEARCH TERM: "CAR WASH"

\begin{tabular}{clllll}
\hline Variables & \multicolumn{1}{c}{ PETR3 } & \multicolumn{1}{c}{ PETR4 } & \multicolumn{1}{c}{ CGAS5 } & \multicolumn{1}{c}{ CSAN3 } & \multicolumn{1}{c}{ UGPA3 } \\
\hline \multirow{2}{*}{ Resid $(-1)^{\wedge} 2$} & 0.1108 & 0.1116 & 0.1177 & 0.0738 & 0.0504 \\
\cline { 2 - 6 } & $(0.0186)^{\star \star \star}$ & $(0.0164)^{\star \star \star}$ & $(0.0289)^{\star \star \star}$ & $(0.0209)^{\star \star \star}$ & $(0.0623)$ \\
\hline \multirow{2}{*}{ GARCH $(-1)$} & 0.8676 & 0.8511 & 0.8171 & 0.8281 & 0.9348 \\
\cline { 2 - 6 } & $(0.0192)^{\star \star \star}$ & $(0.0192)^{\star \star \star}$ & $(0.0481)^{\star \star \star}$ & $(0.0514)^{\star \star \star}$ & $(0.0867)^{\star \star \star}$ \\
\hline
\end{tabular}

Results of the estimates of the adjusted market model using GARCH (1.1) with the parameters estimated by the quasi maximum likelihood estimation (QMLE) to consider the ARCH effects found in the models under analysis. The risk premium, oil futures, gas futures, and DI $3 \mathrm{~m}-1 \mathrm{~m}$ refer to the variables described in Equation 1 , specifically: the excess of the Ibovespa return on the CDI; the premium between the 3-month and 1-month DI rate reflecting the short-term yield curve slope; the return of WTI crude oil and natural gas futures contracts, respectively. The dates refer to dummies with a value equal to 1 for each day comprised in the immediately preceding week, considering Google Trends release and the definition of week adopted, and zero, otherwise. C, Resid $(-1)^{\wedge} 2$ and GARCH(-1) are the coefficients obtained in the Garch $(1,1)$ model estimates, see Equation 2. For CGAS5, the lagged dependent variable was included in the mean equation to filter the existing serial correlation, but the coefficient was omitted from the table. In the upper line is the estimated coefficients followed by the respective standard errors in brackets in the lower line. ${ }^{* \star}$, ** and * refer to the significance at the $1 \%, 5 \%$, and $10 \%$ levels, respectively.

\section{Source: Elaborated by the authors.}

The start of the CW Operation, represented by the dummies on March 17 and 18, 2014, was statistically different from zero at the level of $1 \%$ for all stocks, but with mixed signs. The abnormal returns were positive and significant for the CGAS5 $(0.81 \%)$ and UGPA3 $(1.01 \%)$ shares, while they were negative and significant for PETR3 (-0.99\%), PETR4 (-1.47\%), and CSNA3 (-1.02\%). This reveals at least three facts: 1 . shares of the same sector presented different abnormal returns to the news about the CW Operation; 2 . besides Petrobras, there were other companies that showed abnormal negative returns in these two days, as is the case of CSNA3; 3 . the preferred shares of Petrobras (PETR4) suffered a greater devaluation than the common ones (PETR3), showing a different behavior by the holders of these assets. This is an interesting fact since common shares in Brazil give voting rights, while preferred shares have priority in receiving dividends, which might reflect in the behavior of the investors that owned them.

Such fact makes us believe that common stock investors have long-term oriented behavior and are less susceptible to negative emotions, while preferred stock investors are more suspicious and risk-averse (Corgnet et al., 2016; Fenton-O'Creevy et al., 2011). 
Regarding the dummies that capture the abnormal returns in the weeks with a higher relative search for the term "Car Wash", it can be seen that in weeks 1, 2, and 3, among Petrobras assets, PETR3 showed abnormal negative returns in each of these events, although only marginally significant in the first and third Weeks. PETR4 presented the same performance in Week 3 , i.e., abnormal negative returns at the $10 \%$ significance level. In week 4 , while CGAS5 and UGPA3 devaluated along with CSAN3, although marginally significant, PETR4 showed an abnormal return of $0.27 \%$. Therefore, in an environment of uncertainty, the market mood oscillated between pessimism and optimism, feelings that were revealed in the variation of the assets (Fenton-O'Creevy et al., 2011).

Week 5 reflected a strong joint influence since all the companies in the oil and gas sector in the sample showed abnormal returns, being negative for PETR3 (-0.77\%), PETR4 (-0.75\%), and CSAN3 (-0.42\%). In week 6 , PETR3 presented an abnormal valuation, while CGAS5 and CSAN3 suffered losses, and for PETR4 and UGPA3, the results were not significant.

It is worth mentioning that, although weeks 2 and 3 occurred consecutively, it is possible to notice the individual effect of each one. The same situation occurs with weeks 4, 5, and 6. During week 4, the FP started the 50th phase of the CW Operation, called Operation Sothis II, with searches and seizures due to illicit activities involving negotiations with Transpetro. The results presented in Figure 4.2.1 indicate, for this week, an abnormal negative return for CGAS5 and UGPA3 (5\% significance level), but a positive one for PETR4. However, the event represented in week 5 was significant for Petrobras and affected it negatively in both assets. In addition, it has also captured a somewhat distinct moment in the market, considering that all companies had significant coefficients but with different effects. It is clear that the search or this term for the weeks analyzed managed to capture a movement in the market for the companies. For Petrobras, it may be observed that there were periods evidenced by the dummies in which the assets showed abnormal returns, suggesting that there is an effect between the intensity of the relative search volume offered by Google Trends and the behavior of the Petrobras assets and those from other companies in the oil and gas sector.

The functioning of the market follows the dynamics of the relationship between supply and demand, as investors believe they have the same information. The concrete facts presented at the CW revealed privileges and information asymmetry, resulting in mistrust and consequently affecting the capital inflows (Vuuren, 2002), undermining the investment and its consequent growth (Mauro, 1995). 


\subsection{Results and estimates: corruption}

Figure 4.3.1 shows the results of the estimates using the search term "corruption". As in Figure 4.2.1, the results regarding the modeling of the mean equation are the same. The market risk premium relevance is identified, with PETR4 being the asset with the highest coefficient (1.56), while the returns of the WTI crude oil futures contracts are relevant to explain the returns series. In the modeling of variance equation, it is noticed that the terms ARCH and GARCH are significant and inferior to 1 . The triggering of the CW Operation and the subsequent day, represented by the variable CW 03/17 and 03/18/2014, showed that all the stocks in the sample were exposed to the event at the $5 \%$ significance level.

The CGAS5 and UGPA3 shares had a positive reaction, while PETR3, PETR4, and CSAN3 presented a negative reaction. In relation to the dummy variables, the periods of greater relative search volume on the topic "corruption" showed that, in week 1, only PETR3 and UGPA3 presented abnormal returns different from zero, of which that of the second company being only marginally significant (Figure 4.3.1).

(Figure 4.3.1)

ABNORMAL RETURN FOR THE DATES FROM THE SEARCH TERM: "CORRUPTION"

\begin{tabular}{clllll}
\hline Variables & \multicolumn{1}{c}{ PETR3 } & \multicolumn{1}{c}{ PETR4 } & CGAS5 & CSAN3 & UGPA3 \\
\hline \multirow{2}{*}{ Intercept } & -0.0007 & -0.0004 & 0.0001 & -0.0009 & 0.0000 \\
\cline { 2 - 6 } & $(0.0016)$ & $(0.0017)$ & $(0.0017)$ & $(0.0014)$ & $(0.0015)$ \\
\hline \multirow{2}{*}{ Risk premium } & 1.4760 & 1.5582 & 0.2698 & 0.7654 & 0.6216 \\
\cline { 2 - 6 } & $(0.0480)^{\star \star \star}$ & $(0.0495)^{\star \star \star}$ & $(0.0366)^{\star \star \star}$ & $(0.0466)^{\star \star \star}$ & $(0.0374)^{\star \star \star}$ \\
\hline \multirow{2}{*}{ Oil futures } & 0.3518 & 0.3180 & -0.0107 & 0.0525 & -0.0055 \\
\cline { 2 - 6 } & $(0.0279)^{\star \star \star}$ & $(0.0298)^{\star \star \star}$ & $(0.0218)$ & $(0.0231)^{\star \star}$ & $(0.0162)$ \\
\hline \multirow{2}{*}{ Gas futures } & 0.0057 & 0.0022 & 0.0119 & 0.0117 & -0.0076 \\
\cline { 2 - 6 } & $(0.0137)$ & $(0.0140)$ & $(0.0150)$ & $(0.0190)$ & $(0.0133)$ \\
\hline \multirow{2}{*}{ DI 3m-1m } & 0.0096 & 0.0071 & -0.0025 & 0.0068 & 0.0003 \\
\cline { 2 - 6 } & $(0.0150)$ & $(0.0165)$ & $(0.0165)$ & $(0.0131)$ & $(0.0133)$ \\
\hline
\end{tabular}


(Figure 4.3.1 (conclusion))

ABNORMAL RETURN FOR THE DATES FROM THE SEARCH TERM: "CORRUPTION"

\begin{tabular}{|c|c|c|c|c|c|}
\hline Variables & PETR3 & PETR4 & CGAS5 & CSAN3 & UGPA3 \\
\hline \multirow{2}{*}{$\begin{array}{c}\text { OLJ - 03/17 and } \\
\text { 18/03/2014 }\end{array}$} & -0.0097 & -0.0145 & 0.0082 & -0.0102 & 0.0101 \\
\hline & $(0.0008)^{\star \star \star}$ & $(0.0012)^{\star \star \star}$ & $(0.0025)^{\star \star \star}$ & $(0.0007)^{\star \star \star}$ & $(0.0007)^{\star \star \star}$ \\
\hline \multirow{2}{*}{$\begin{array}{c}\text { Week } 1 \text { - } \\
\text { 13/03/2016 }\end{array}$} & -0.0081 & -0.0020 & -0.0009 & 0.0017 & -0.0015 \\
\hline & $(0.0025)^{\star \star \star}$ & $(0.0068)$ & $(0.0015)$ & $(0.0020)$ & $(0.0009)^{\star}$ \\
\hline \multirow{2}{*}{$\begin{array}{c}\text { Week } 2 \text { - } \\
\text { 30/09/2018 }\end{array}$} & 0.0042 & 0.0047 & -0.0075 & -0.0073 & 0.0025 \\
\hline & $(0.0016)^{\star \star \star}$ & $(0.0023)^{\star \star}$ & $(0.0036)^{\star \star}$ & $(0.0029)^{\star \star}$ & $(0.0049)$ \\
\hline \multirow{2}{*}{$\begin{array}{c}\text { Week } 3 \text { - } \\
\text { 07/10/2018 }\end{array}$} & 0.0096 & 0.0162 & 0.0157 & 0.0104 & 0.0127 \\
\hline & $(0.0022)^{\star \star \star}$ & $(0.0024)^{\star \star \star}$ & $(0.0038)^{\star \star *}$ & $(0.0053)^{\star \star}$ & $(0.0029)^{\star \star \star}$ \\
\hline \multirow{2}{*}{ C } & 0.0000 & 0.0000 & 0.0000 & 0.0000 & 0.0000 \\
\hline & $(0.0000)$ & $(0.0000)^{\star \star \star}$ & $(0.0000)^{\star \star}$ & $(0.0000)^{\star \star}$ & $(0.0000)$ \\
\hline \multirow{2}{*}{ Resid $(-1)^{\wedge} 2$} & 0.1081 & 0.1089 & 0.1169 & 0.0753 & 0.0484 \\
\hline & $(0.0199)^{\star \star \star}$ & $(0.0134)^{\star \star \star}$ & $(0.0281)^{\star \star \star}$ & $(0.0217)^{\star \star \star}$ & $(0.0691)$ \\
\hline \multirow{2}{*}{ GARCH(-1) } & 0.8718 & 0.8565 & 0.8174 & 0.8261 & 0.9374 \\
\hline & $(0.0199)^{\star \star \star}$ & $(0.0161)^{\star \star \star}$ & $(0.0454)^{\star \star \star}$ & $(0.0525)^{\star \star \star}$ & $(0.0937)^{\star \star \star}$ \\
\hline
\end{tabular}

See note in Figure 4.2.1.

However, in weeks 2 and 3, as shown in Figure 4.3.1, the Petrobras assets presented abnormal positive returns compared with the other stocks in the latter; all the other companies in the sector presented gains. This is interesting since this period basically comprises the final moments of the first round of the 2018 presidential campaign, showing that investors may have seen the proposals of the candidates as opportunities to fight corruption. Therefore, the search for this term does not seem to be exactly related to the effects of the CW Operation but to the drive for its eradication.

The CW Operation took place in a scenario of financial crisis and recession as evidenced by the studies of Barbosa Filho (2017), Pessôa (2017), and OECD (2018). The analysis of the impact of the CW Operation cannot be decontextualized from the economic scenario because it goes beyond the 
intramural effects-of the organization, influencing the national and international environment. Bonell and Meyer (2015) and Voyer and Beamish (2004) showed the negative impact of corruption on investments since they lead to a lack of trust among players, with distorted decision making due to information asymmetry. The study of T. Clarke (2005) about the Enron case was one of the best known and most studied cases of corruption with disastrous corporate and investor market effects. The importance of the social responsibility of organizations is highlighted, based on the evidence of the breach of confidence by society and investors.

In general, investors in the capital market suffered the effect of all the corruption identified by the CW Operation. The flow of capital seems to have opted for assets of greater confidence than PETR3 and PETR4 during the beginning of the operation. The data seem to converge with the research findings that show that investors in the capital markets were subject to: the news bias (Shefrin, 2002) since it was evident in this study the relation among the terms most used on the internet and the market movement; the emotional bias detected by the change in the capital flow of Petrobras assets to other assets of greater investor confidence (Severin \& Tankard Jr., 2001); and the social bias identified by a collective movement of divestments from Petrobras assets to other stocks (Fenton-O'Creevy et al., 2011; Prosad et al., 2015).

\section{CONCLUSION}

This study investigated the effects of the CW Operation on the Brazilian capital market with a focus on Petrobras, which was the main object of investigations, and other listed companies in the oil and gas sector.

The news about the CW Operation and the economic and political crisis in Brazil began to occupy more space in all media, favoring the involvement of the population. News with the topics "Car Wash" and "corruption" began to be searched and commented on on the internet and social networks. The news informed and influenced the society about the direction of the investigation, becoming a fertile environment for the occurrence of cognitive and emotional biases.

Capital market investors could not avoid being influenced by their emotions that were represented by their "behavior" in asset trading. Using dummy variables inserted to capture the abnormal returns in the weeks with a greater search volume for the terms "Car Wash" and "corruption", based on the Google Trends tool, there was a significant reaction in the 
stock prices due to the analyzed events. The uncertainty about future returns in the stock market caused a wave of pessimism and optimism demonstrated by the variability of the assets. The capital flow seems to have presented a rejection to the PETR3 and PETR4 assets because after the deflagration of the operation there were negative abnormal returns as well as abnormal (de)valuations for Petrobras and other companies of the sector portrayed in the dummies and inserted in the estimates. This study presented results that show the harmful effects on the assets in the capital market and emphasized that, in an environment of distrust and uncertainty caused by corruption, the resulting instability affects the stocks of the company.

It should also be added, as implications of this study, that managers may reflect on these results and seek measures to prevent the company from getting involved again in new cases of corruption. Public policymakers at the control agencies may develop policies that may prevent new cases of corruption. Academics are encouraged to engage in dialogues about corruptionrelated issues and their resulting effects on organizations and the society.

In addition, the study highlighted the impact of emotions and biases that might result from corruption, which demonstrates that the methodology adopted might be applied to other studies as a measure of investor attention and in order to identify human behavior.

As limitations of this investigation, it should be noted that the results presented are restricted to the sample and to the study interval, which does not allow us to generalize. For future investigations, the study of relevant dates from Google Trends might be extended to other companies related to the public power and to other sectors, such as the civil construction, which was also affected by the operation, in order to identify any combined movement.

\section{OS EFEITOS DA OPERAÇÃO "LAVA JATO" NO MERCADO DE CAPITAIS BRASILEIRO: O CASO PETROBRAS}

\section{RESUMO}

Objetivo: O estudo pretende identificar os efeitos da Operação Lava Jato no mercado de capitais brasileiro com foco na empresa estatal Petróleo Brasileiro S.A. (Petrobras), incluindo nesta análise outras companhias de capital aberto que pertencem ao setor de Petróleo e Gás. 
Originalidade/valor: A pesquisa é relevante, porque avança na discussão sobre a influência da Operação Lava Jato no preço de ações no contexto brasileiro. O estudo contribui para evidenciar o uso da ferramenta Google Trends como uma medida de atenção do mercado e seus efeitos.

Design/metodologia/abordagem: Este estudo é uma pesquisa quantitativa, baseada em evidências do volume de pesquisa online em relação com o movimento dos preços das ações. A amostra foi composta de dados da Petrobras e de outras companhias pertencentes ao setor de Petróleo e Gás no período de 2 de janeiro de 2013 a 28 de dezembro de 2018. A definição das datas mais relevantes foi realizada através do índice de volume de pesquisa para os termos "Lava Jato" e "corrupção", obtidos a partir da ferramenta Google Trends. O modelo GARCH $(1,1)$ foi adotado nas estimações.

Resultados: Os resultados obtidos a partir das dummies incluídas para capturar os retornos anormais, mostraram uma reação significativa nos comportamentos dos ativos. O fluxo do capital parece ter optado por ativos de maior confiança do que PETR3 e PETR4 em algumas das semanas estudadas depois do início da Operação. Pode-se concluir que, de forma geral, a deflagração da Lava Jato foi relevante e trouxe certa instabilidade para outras empresas do setor.

\section{PALAVRAS-CHAVE}

Operação Lava Jato. Corrupção. Petrobras. Sentimento do investidor. Google Trends.

\section{REFERENCES}

Asiedu, E., \& Freeman, J. (2009). The effect of corruption on investment growth: Evidence from firms in Latin America, Sub-Saharan Africa, and transition countries. Review of Development Economics, 13(2), 200-214. doi:10.1111/j.1467-9361.2009.00507.x

Baker, M., \& Wurgler, J. (2007). Investor sentiment in the stock market. Journal of Economic Perspectives, 21 (2), 129-151. doi:10.1257/jep.21.2.129

Ball, R., \& Brown, P. (1968). An empirical evaluation of accounting income numbers.Journal of Accounting Research, 6 (2), 159-178. doi:10.2307/2490232 
Banco Central do Brasil (2015, October 20). Focus: relatório de mercado. Banco Central do Brasil. Retrieved from http://www.bcb.gov.br/pec/GCI/ PORT/readout/R20151030.pdf

Barber, B. M., \& Odean, T. (2008). All that glitters: The effect of attention and news on the buying behavior of individual and institutional investors. Review of Financial Studies, 21 (2), 785-818. doi:10.1093/rfs/hhm079

Barbosa Filho, F. de H. (2017). A crise econômica de 2014/2017. Estudos Avançados, 31 (89), 51-60. doi:10.1590/s0103-40142017.31890006

Barkemeyer, R., Preuss, L., \& Ohana, M. (2018). Developing country firms and the challenge of corruption: Do company commitments mirror the quality of national-level institutions? Journal of Business Research, 90(C), 26-39. doi:10.1016/j.jbusres.2018.04.025

Bijl, L., Kringhaug, G., Molnár, P., \& Sandvik, E. (2016). Google searches and stock returns. International Review of Financial Analysis, 45(C), 150-156. doi:10.1016/j.irfa.2016.03.015

Blitz, D., Pang, J., \& van Vliet, P. (2013). The volatility effect in emerging markets. Emerging Markets Review, 16(C), 31-45. doi:10.1016/j.ememar. 2013.02.004

Bollerslev, T. (1986). Generalized autoregressive conditional heteroskedasticity. Journal of Econometrics, 31 (3), 307-327. doi:10.1016/0304-4076(86) 90063-1

Bonell, M. J., \& Meyer, O. (Eds.) (2015). The impact of corruption on international commercial contracts. Nova York, NY: Springer. doi:10.1007/978-3319-19054-9

Borges, B. (2017, Setembro). Impacto dos erros (reais) da nova matriz tem sido muito exagerado. Retrieved from blogdoibre.fgv.br/posts/impactodos-erros-reais-da-nova-matriz-tem-sido-muito-exagerado

Brunetti, A., \& Weder, B. (2003). A free press is bad news for corruption. Journal of Public Economics, 87(7-8), 1801-1824. doi:10.1016/S0047-2727 (01)00186-4

Bulnes, M. J. (2013). El proceso penal en los sistemas del Common Law y Civil Law: Los modelos acusatorio e inquisitivo en el pleno siglo XXI. Justicia: Revista de Derecho Procesal, (2), 201-304. Retrieved from dialnet. unirioja.es/servlet/articulo? codigo $=4584713$

Campos, J. E., Lien, D., \& Pradhan, S. (2008). The impact of corruption on foreign direct investment. The Journal of World Investment \& Trade, 27(6), vii-273. doi:10.1163/221190008X00016 
Clarke, R. G., de Silva, H., \& Thorley, S. (2006). Minimum-variance portfolios in the U.S. equity market. The Journal of Portfolio Management, 33(1), 10-24. doi:10.3905/jpm.2006.661366

Clarke, T. (2005). Accounting for Enron: Shareholder value and stakeholder interests. Corporate Governance: An International Review, 13(5), 598-612. doi:10.1111/j.1467-8683.2005.00454.x

Connors, W., \& Magalhaes, L. (2015, April 6). How Brazil's “Nine Horsemen” cracked a bribery scandal. The Wall Street Journal. Retrieved from wsj.com/ articles/how-brazils-nine-horsemen-cracked-petrobras-bribery-scandal1428334221

Corgnet, B., Espín, A. M., Hernán-González, R., Kujal, P., \& Rassenti, S. (2016). To trust, or not to trust: Cognitive reflection in trust games. Journal of Behavioral and Experimental Economics, 64, 20-27. doi:10.1016/j.socec. 2015.09.008

Da, Z., Engelberg, J., \& Gao, P. (2011). In search of attention. The Journal of Finance, 66(5), 1461-1499. https://doi.org/10.1111/j.1540-6261.2011. 01679.x

Da, Z., Engelberg, J., \& Gao, P. (2015). The sum of all FEARS investor sentiment and asset prices. Review of Financial Studies, 28(1), 1-32. https://doi. org/10.1093/rfs/hhu072

Ebeling, F. (2016). Variedades de capitalismo e complementaridades institucionais: Uma análise da política petrolífera brasileira e da viabilidade do "Projeto Pré-Sal". Cadernos EBAPE.BR, 14(Edição Especial), 418-439. doi:10.1590/1679-395117001

Engle, R. F. (1982). Autoregressive conditional heteroscedasticity with estimates of the variance of United Kingdom inflation. Econometrica, 50(4), 987-1007. doi:10.2307/1912773

Falcão, A. R. S., \& Bonato, G. (2017). Sistema de precedentes judiciais na ordem jurídica brasileira: análise do instituto como mecanismo de gestão e administração da justiça e das reformas empreendidas à sua introdução. Revista de Política Judiciária, Gestão e Administração da Justiça, 3(2), 20-35. doi:10.26668/IndexLawJournals/2525-9822/2017.v3i2.2569

Fama, E. F., Fisher, L., Jensen, M. C., \& Roll, R. (1969). The adjustment of stock prices to new information. International Economic Review, 10(1), 1-21. doi: $10.2307 / 2525569$

Fenton-O'Creevy, M., Soane, E., Nicholson, N., \& Willman, P. (2011). Thinking, feeling and deciding: The influence of emotions on the decision making and performance of traders. Journal of Organizational Behavior, 32(8), 1044-1061. doi:10.1002/job.720 
Fundação Getulio Vargas - FGV. (2017, Outubro). Comunicado de Datação de Ciclos Mensais Brasileiros - Out/2017 - CODACE. Retrieved from https://portalibre.fgv.br/data/files/F3/C1/F8/E8/A18F66108DDC4E 66CA18B7A8/Comite de Data_o de Ciclos Econ_micos - Comunicado de 30_10_2017_1_.pdf

Habib, M., \& Zurawicki, L. (2002). Corruption and foreign direct investment. Journal of International Business Studies, 33(2), 291-307. doi:10.1057/ palgrave.jibs. 8491017

Hines, J. (1995). Forbidden payment: Foreign bribery and american business after 1977. Retrieved from https://doi.org/10.3386/w5266

Jain, A. K. (2001). Corruption: A review. Journal of Economic Surveys, 15(1), 71-121. doi:10.1111/1467-6419.00133

Kim, N., Lučivjanská, K., Molnár, P., \& Villa, R. (2019). Google searches and stock market activity: Evidence from Norway. Finance Research Letters, 28, 208-220. doi:10.1016/j.frl.2018.05.003

Markowitz, H. (1952). Portfolio selection. The Journal of Finance, 7(1), 77-91. doi:10.1111/j.1540-6261.1952.tb01525.x

Mauro, P. (1995). Corruption and growth. The Quarterly Journal of Economics, 110(3), 681-712. doi:10.2307/2946696

OCDE. (2015). Relatórios econômicos da OCDE: Brasil 2015 (pp. 1-50). Retrieved from http://www.oecd.org/economy/surveys/Brasil-2015-resumo.pdf

OCDE. (2018). Relatórios econômicos OCDE: Brasil 2018. Retrieved from https://doi.org/10.1787/9789264290716-pt

Padula, A. J. A., \& Albuquerque, P. H. M. (2018). Corrupção governamental no mercado de capitais: Um estudo acerca da operação lava jato. Revista de Administração de Empresas, 58(4), 405-417. doi:10.1590/s0034-7590201 80406

Pessôa, S. (2017). Debate dos impactos da Nova Matriz Econômica: A visão mais crítica. Revista Conjuntura Econômica, 71(10), 10-11. Retrieved from http://bibliotecadigital.fgv.br/ojs/index.php/rce/article/view/74872

Petrobras. (2014). Relatório da administração 2014 (pp. 1-93). Retrieved from https://www.investidorpetrobras.com.br/ptb/8716/RelatriodaAdministrao 2014.pdf

Polícia Federal. (2019). Operação Lava Jato - Fases. Retrieved from http:// www.pf.gov.br/imprensa/lava-jato 
Prosad, J. M., Kapoor, S., \& Sengupta, J. (2015). Theory of behavioral finance. In Z. Copur (Ed.), Handbook of research on behavioral finance and investment strategies: decision making in the financial industry (pp. 1-24). Retrieved from https://doi.org/10.4018/978-1-4666-7484-4.ch001

Rotberg, R. I. (Ed.). (2019). Corruption in Latin America: How politicians and corporations steal from citizens. Cham, Switzerland: Springer. doi:10.1007/ 978-3-319-94057-1

Sabet, S. A. H., Cam, M.-A., \& Heaney, R. (2012). Share market reaction to the BP oil spill and the US government moratorium on exploration. Australian Journal of Management, 37(1), 61-76. doi:10.1177/0312896211 427321

Santana, C. V. S., Santos, L. P. G. dos, Carvalho Júnior, C. V. de O., \& Martinez, A. L. (2020). Investor sentiment and earnings management in Brazil. Revista Contabilidade E Finanças, 31 (83), 283-301. doi:10.1590/ 1808-057x201909130

Severin, W. J., \& Tankard Jr., J. W. (2001). Communication theories: Origins, methods and uses in the mass media (5th ed.). New York: Addison Wesley Longman.

Shefrin, H. (2002). Beyond greed and fear: Understanding behavioral finance and the psychology of investing. New York, NY: Oxford University Press.

Taffler, R. J., \& Tuckett, D. A. (2010). Emotional finance: The role of the unconscious in financial decisions. In H. Kent Baker \& J. R. Nofsinger (Eds.), Behavioral finance: Investors, corporations, and markets (pp. 95-112). New Jersey, NJ: Wiley.

Voyer, P. A., \& Beamish, P. W. (2004). The effect of corruption on Japanese foreign direct investment. Journal of Business Ethics, 50(3), 211-224. doi:10.1023/B:BUSI.0000024737.57926.bf

Vuuren, H. Van. (2002). Corruption, perception and foreing direct investiment. African Security Review, 11(3), 67-75. doi:10.1080/10246029.2002. 9627970

Warf, B. (2019). Global corruption from a geographic perspective. doi:10.1007/9783-030-03478-8

White, H. (1982). Maximum likelihood estimation of misspecified models. Econometrica, 50(1), 1. doi:10.2307/1912526

Yoshinaga, C. E. (2009). A relação entre índice de sentimento de mercado e as taxas de retorno das ações: Uma análise com dados em painel (Universidade de São Paulo). doi:10.11606/T.12.2009.tde-17122009-105238 


\section{AUTHOR NOTES}

Eliana M. M. F. Torga, PhD from the Faculty of Economic Sciences, Federal University of Minas Gerais (UFMG); Carolina M. S. Roma, PhD from the Faculty of Economic Sciences, UFMG; Mirian A. Pires, PhD from the Brazilian School of Public and Business Administration (Ebape), Getulio Vargas Foundation (FGV); Paula M. S. Roma, PhD from the Institute of Exact Sciences, UFMG; Bruno P. Ferreira, PhD from the Faculty of Economic Sciences, UFMG.

Eliana M. M. F. Torga is now adjunct professor at the Professional Master's Program in Administration of UNA University Center; Carolina M. S. Roma is now adjunct professor at the Institute of Economic, Administrative and Accounting Sciences (Iceac) of Federal University of Rio Grande (Furg); Mirian A. Pires is now professor at the Center for Legal and Economic Sciences (CCJE) of Federal University of Espírito Santo (Ufes); Paula M. S. Roma is now alumnus at the Institute of Exact Sciences of UFMG; Bruno P. Ferreira is now associate professor at the Faculty of Economic Sciences of UFMG.

Correspondence concerning this article should be addressed to Eliana M. M. F. Torga, Rua Guajajaras, 175, Centro, Belo Horizonte, Minas Gerais, Brazil, CEP 30180-100.

E-mail: elianatorga@gmail.com

EDITORIAL BOARD

Editor-in-chief

Gilberto Perez

Associated editor

Gardênia da Silva Abbad

Technical support

Vitória Batista Santos Silva

\section{EDITORIAL PRODUCTION}

Publishing coordination

Jéssica Dametta

Language editor

Daniel de Almeida Leão

Layout designer

Emap

Graphic designer

Libro 